\title{
Nutritional Composition of Raw, Malted and Popped Finger Millet (Eleusine coracana) Varieties
}

\author{
Soubhagyalaxmi P. Hiremath* and K. Geetha \\ Department of Food Science and Nutrition, University of Agricultural Sciences, \\ Bengaluru, Karnataka, India \\ *Corresponding author
}

\section{A B S T R A C T}

\section{Keywords}

Finger millet, Nutrients, Malting, Popping

Article Info

Accepted:

07 January 2019

Available Online:

10 February 2019

\section{Introduction}

Finger millet (Eleusine coracana) also locally known as Ragi forms the primary food source for millions of people in tropical and dryland regions. It is one of the important small millets cultivated in many South Asian and African countries. It is one of the oldest food crops and referred to as 'Artha-Kandaka' in the ancient Sanskrit literature, which means 'Dancing grain'. Finger millet also have nutritional qualities superior than that of rice. Finger millet is especially valuable as it contains the amino acid methionine, which is lacking in starchy staples such as polished rice. It is usually used for the preparation of flour, pudding, porridge and roti, but with the changes in scenario of utilisation of processed products and awareness of the consumers about the health benefits, finger millet has gained importance because of its functional components (Wadikar et al., 2007). Finger millet is mostly consumed in its native forms but today due to urbanisation and modernisation processed finger millet products are of great demand. It is at most important to see the effects of different processing techniques on nutritional quality of finger millet which otherwise in its native form is of great help to mankind to 
maintain/regulate certain metabolic disorders. Hence an investigation was undertaken to study the nutritional composition of raw, malted and popped finger millet varieties.

\section{Materials and Methods}

Five finger millet (Eleusine coracana) varieties selected for study were procured from All India Co-ordinated Small millets Improvement Project, University of Agricultural Sciences, Bengaluru. The varieties selected were GPU 66, GPU 67, GPU 71, MR 6 and PR 202. They were cleaned to remove foreign materials and impurities. Further were subjected to malting and popping.

Malting of Finger millet: Finger millet seeds were washed with water for 5 times and soaked in water for 5 hrs. Excess water was drained, seeds were tied in a muslin cloth and $5 \mathrm{~kg}$ weight was kept on it. These seeds were germinated at $27 \pm 3^{\circ} \mathrm{C}$ for $24 \mathrm{hr}$ and dried in shade for 2 days. The germinated shade dried finger millet seeds were subjected to kilning and devegetated. These seeds were grounded into flour by using the electric grinder (Plate 1) (Malleshi and Desikachar, 1986).

\section{Popping of Finger millet:}

After determining the moisture in the sample by oven drying methods, water was sprinkled on the grain to raise the moisture content to 19 percent, mixed well and grain equilibrated in a closed airtight container for $24 \mathrm{hrs}$ prior to popping. After 24 hours the equilibrated grain were added in an iron frying pan, the temperature of which was maintained at 175 $200^{\circ} \mathrm{C}$. When popping sound was stopped the pan was removed from the flame (Plate 2) (Malleshi and Desikachar, 1981).

The nutrients for the research sample in its raw, malted and popped form were moisture, protein, fat, crude fibre, ash and total dietary. Carbohydrate and energy values were computed.

The AOAC (1980) methods were followed for estimation of moisture, protein, fat, crude fibre, ash. Carbohydrate and energy were computed by differential method. The total dietary fibre was analysed by AOAC (1995) method.

\section{Statistical analysis}

For comparison of nutrient content of raw, malted and popped finger millet two way analysis of variance test was applied on the means of two replications for different varieties.

\section{Results and Discussion}

Percent germination of different finger millet varieties under study ranged from 98 to 99 per cent (Table 1) which is in tune with findings of study by Kumari and Srivastava (2000) on 'Nutritive value of malted flours of finger millet genotypes and their use in the preparation of Burfi'.

Percent malt recovery of different finger millet varieties which ranged from 75 to 82 per cent (Table 1) in the present study is in tune with the findings of the study conducted by Pawar and Pawar (1997) and Malleshi and Klopfenstein (1998) on 'Nutrient composition and amino acid contents of malted sorghum, pearl millet and finger millet and their milling fractions'. The variation in malt recovery may be due to the moisture and fibre content in the varieties. Higher the moisture and fibre content lower is the malt recovery.

A study conducted by Shukla et al., (1986) on of finger millet for puffing yield found that puffing yield ranged from 66 to 95.3 per cent. But the popping percent of the finger millet 
varieties under study ranged from 31 to 76 per cent (Table 1) which is in tune with the findings of the study conducted by Shukla $e t$ al., (1986) on eight varieties of finger millet for puffing yield but not on par with the findings of Shukla et al., (1986) on eight varieties of finger millet.

Moisture content of cereals and millets ranges from 10 to 14 per cent. Similar trend was also observed in raw finger millet varieties under study which ranged from 11.9 to 12.35 per cent. However the moisture content of the varieties decreased in malt flour which ranged from 6.0 to 9.1 per cent and also popped flour ranging from 3.5 to 4.25 per cent. The reason may be due to drying and roasting in case of malting and in case of popping due to heating at high temperature where there is loss of moisture content. Similar trend was reported in popped finger millet varieties by Madhusmita Sahoo (2003). A study by Desai (2009) also reported the moisture content of raw and malted ragi to be 12.67 per cent. The findings are also in tune with the findings of Kumari and Srivastava (2000) on nutritive value of malted flours of finger millet genotypes and their use in the preparation of burfi.

Protein content appears to be the dominant chemical constituent that influences the grain hardness, milling, popping and malting characteristics. This parameter therefore could have as one of the basic quality indicator in millet breeding programme. Protein content of finger millet in general is $7.3 \mathrm{~g} / 100 \mathrm{~g}$ (Gopalan et al., 2007). In present study the Protein content of raw finger millet varieties ranged from 6.25 to $11.87 \mathrm{~g} / 100 \mathrm{~g}$ which was on par with the results of the study conducted by Shayo et al., in 2001 in which the protein ranged from 8.91 to $12.5 \mathrm{~g}$. The mean protein content of malted grain was $8.18 \mathrm{~g}$ and that of popped was $5.84 \mathrm{~g}$, which was slightly lower than that reported by Choudhury et al.,
(2010), but on par with the findings reported by Shayo et al., (2001) where in the protein content of malted finger millet ranged from 8.28 to $11.8 \mathrm{~g}$. The protein content of the popped finger millet under study is on par with the findings of Madhusmita Sahoo (2003) where in the popped finger millet protein content was $6.2 \mathrm{~g}$. After malting and popping the protein content of finger millet was decreased compared to raw form. The decrease in protein content after malting may be due to hydrolysis of native protein to low molecular weight proteins or peptides and increase in enzyme activity (Shayo et al., 2001) (Table 2).

Fat is an important component of diet and serves number of functions in the body. It is a concentrated source of energy and also important source of essential fatty acids. It is also necessary for proper utilisation of fat soluble vitamins. According to Gopalan et al., (2007) the fat content of raw finger millet is $1.3 \mathrm{~g}$. In the present study the fat content of raw finger millet varieties ranged from 1.3 to $1.9 \mathrm{~g}$ which was on par with the findings of Kumari and Srivastava (2000) where in the fat content ranged from 1.0 to $2.0 \mathrm{~g}$ and also according to Wadikar et al., (2007) the fat content ranged from 1.3 to 1.9 per cent. In the present study application of processing method such as malting decreased the fat content which was found to be ranging from 0.8 to $1.2 \mathrm{~g} / 100 \mathrm{~g}$ but popping increased the fat content ranging from 1.60 to $2.25 \mathrm{~g} / 100 \mathrm{~g}$. This may be because the hydrolysis of lipid and oxidation of fatty acids take place during germination of seeds. The hydrolysed products do not accumulate in the seed, but the glycerol becomes a part of carbohydrate pool and the fatty acids are oxidised through $\square$ and $\beta$ oxidation, resulting in decrease in fat on malting (Choudhury et al., 2010). Significant increase in fat content during puffing was observed which may be due to the increased polar lipids which may improve 
the functionality of the puffed millet flour in processed products (Premavalli et al., 2005). According to Gopalan et al., (2007) total ash content of finger millet is $2.7 \mathrm{~g}$. Similar trend was also observed in raw finger millet varieties under study which ranged from 2.05 to $2.45 \mathrm{~g}$. However the total ash content of the varieties decreased in malted which ranged from 1.75 to $2.00 \mathrm{~g} / 100 \mathrm{~g}$ and popped form ranged from 1.2 to $1.7 \mathrm{~g} / 100 \mathrm{~g}$. The reason may be due to the removal of seed coat during malting and due to greater concentration of minerals present in the germ and the bran layers than in the endosperm which contribute to a greater extent towards the reduced amount of total ash content in popped finger millet (Choudhury et al., 2010). Similar trends were observed by Shayo et al., (2001) for malted form of finger millet and by Madhusmita Sahoo (2003) for popped form of finger millet.

Crude fibre is an important biological and nutritive component of human body. It adds bulk to the diet. A high fibre diet is used in the prevention and treatment of constipation. Finger millet contains $3.6 \mathrm{~g} / 100 \mathrm{~g}$ of crude fibre. Similar results were observed in raw finger millet varieties under study which ranged from 2.65 to $3.40 \mathrm{~g}$. The variation may be due to genotypes. Crude fibre was found to reduce after processing of finger millet in present investigation. The results of the present study showed that in malt flour crude fibre ranged from 2.35 to $3.10 \mathrm{~g} / 100 \mathrm{~g}$ and that in popped flour from 2.00 to $2.45 \mathrm{~g} / 100 \mathrm{~g}$. Reduction in crude fibre content during malting might be due to the type of grain and degree of removal of seed coat and also due to decrease in neutral detergent fibre on malting which occurs because of cell wall degradation during sprouting process and also the exclusion of rootlets and shoots of sprouts (Kumari and Srivastava (2000) and Choudhury et al, 2010. In millet seeds there are two sources of fibre namely hull or pericarp and the cell wall structural components. During popping, the endosperm puffs out and localized rupture of the cell wall occurs in the expanded endosperm. In this process, the seed coat gets removed to some extent, which could be the reason for lower fibre content in popped sample compared to that of raw samples. However similar trend was observed by Malleshi and Klopfenstein (1998) (Fig. 1).

Carbohydrate content of finger millet is found to be $72 \mathrm{~g} / 100 \mathrm{~g}$ (Gopalan et al., 2007). Similar trend was also observed in raw finger millet varieties in the present study which ranged from 69 to $75 \mathrm{~g} / 100 \mathrm{~g}$. However the carbohydrate content of the finger millet varieties increased in malted and popped form. Carbohydrate in malted form ranged from 77 to $79 \mathrm{~g} / 100 \mathrm{~g}$ and in popped form from 83 to $85 \mathrm{~g} / 100 \mathrm{~g}$ (Table 3 ). The reason may be during germination, there would be partial degradation of amylopectin and increase in amylose content which contributes to the total carbohydrate of malted form of finger millet (Gokavi and Malleshi, 2000). Carbohydrate content in popped form was significantly higher which may be due to the fact that popped seeds were concentrated more with endosperm which contributes 94 per cent of starch to the kernel (Choudhury et al., 2010).

According to Gopalan et al., (2007) the energy content of finger millet is $328 \mathrm{Kcal}$. Similar trend was observed in raw finger millet varieties. However energy values increased during the process of malting and popping of finger millet. This increase energy values in finger millet may be due to increase in the amount of carbohydrate content (Choudhury et al., 2010 and Madhusmita Sahoo, 2003). Dietary fibre protects against hyperglycemia. It is also helpful in relieving constipation and reduces the risk of colon cancer. Total dietary fibre, soluble dietary fibre and insoluble dietary fibre content of finger millet was $11.5,1.6$ and $9.9 \mathrm{~g} / 100 \mathrm{~g}$ (Gopalan et al., 2007). 
Table.1 Germination, malt recovery and popping percent of finger millet varieties

\begin{tabular}{|c|c|c|c|}
\hline Varieties & Germination \% & Malt recovery \% & Popping \% \\
\hline GPU 66 & 98 & 78 & 66 \\
\hline GPU 67 & 98 & 79 & 59 \\
\hline GPU 71 & 99 & 82 & 76 \\
\hline MR 6 & 98 & 75 & 31 \\
\hline PR 202 & 98 & 76 & 54 \\
\hline Mean & 98.2 & 78 & 57.2 \\
\hline & SE & CD at 5\% & F value \\
\hline V & 0.387 & 1.167 & $*$ \\
\hline PM & 0.300 & 0.904 & $*$ \\
\hline
\end{tabular}

*Significant at $\mathrm{p}(\leq 0.05)$; V- Variety; PM-Processing methods; V X PM- Variety X Processing method

Table.2 Macronutrients in raw, malted and popped finger millet

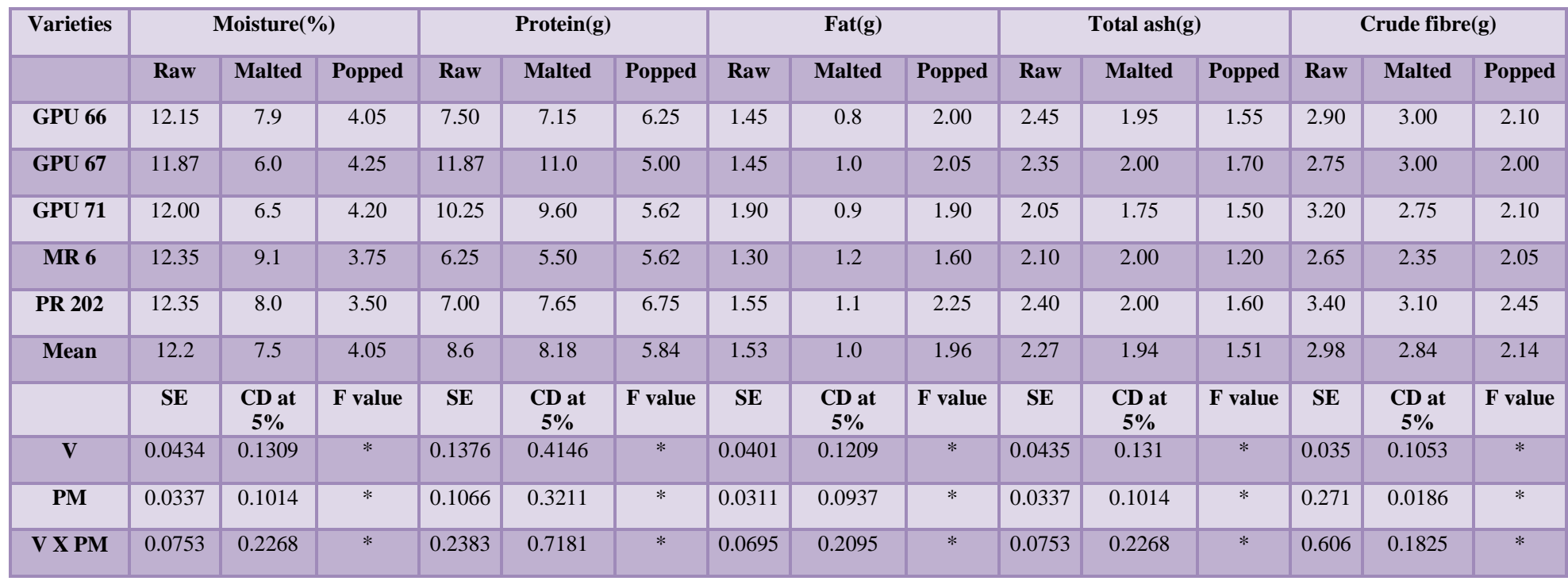

*-Significant at p $(\leq 0.05)$; V- Variety; PM-Processing methods; V X PM- Variety X Processing methods

Table.3 Carbohydrate and Energy content in raw, malted and popped finger millet (computed values)

\begin{tabular}{|l|c|c|c|c|c|c|}
\hline \multirow{2}{*}{ Varieties } & \multicolumn{3}{|c|}{ Carbohydrates(g) } & \multicolumn{3}{c|}{ Energy(Kcal) } \\
\cline { 2 - 7 } & Raw & Malted & Popped & Raw & Malted & Popped \\
\hline GPU 66 & 73 & 79 & 84 & 337 & 352 & 379 \\
\hline GPU 67 & 69 & 77 & 85 & 339 & 361 & 378 \\
\hline GPU 71 & 70 & 78 & 84 & 340 & 360 & 378 \\
\hline MR 6 & 75 & 79 & 85 & 338 & 352 & 380 \\
\hline PR 202 & 73 & 78 & 83 & 335 & 353 & 381 \\
\hline Mean & 72 & 78 & 84 & 338 & 355 & 379 \\
\hline & SE & CD & F value & SE & CD & F value \\
\hline V & 0.1506 & 0.4539 & $*$ & 0.3752 & 1.1307 & $*$ \\
\hline PM & 0.1167 & 0.3516 & $*$ & 0.2907 & 0.8758 & $*$ \\
\hline V X PM & 0.2609 & 0.7861 & $*$ & 0.6499 & 1.9584 & $*$ \\
\hline
\end{tabular}

*-Significant at $\mathrm{p}(\leq 0.05)$; V- Variety; PM-Processing methods; V X PM- Variety X Processing methods 
Fig.1

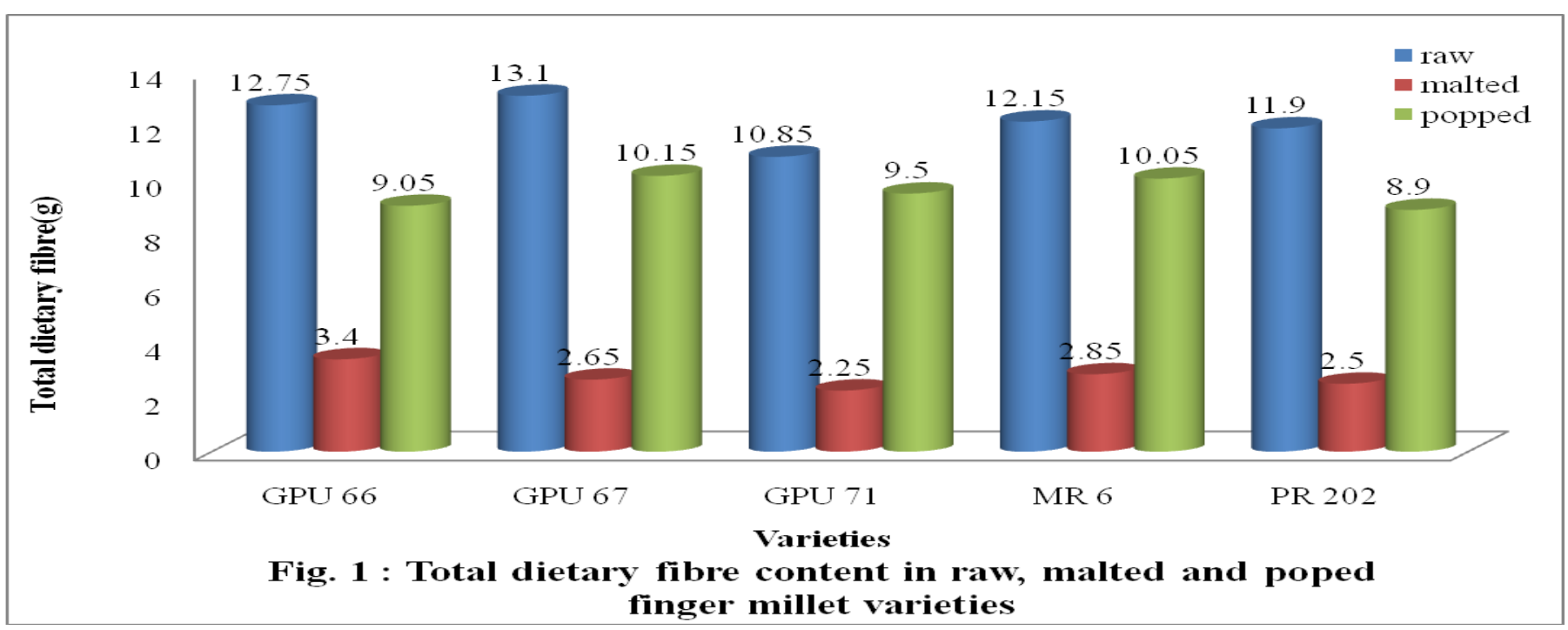

Plate.1 Malted finger millet varieties
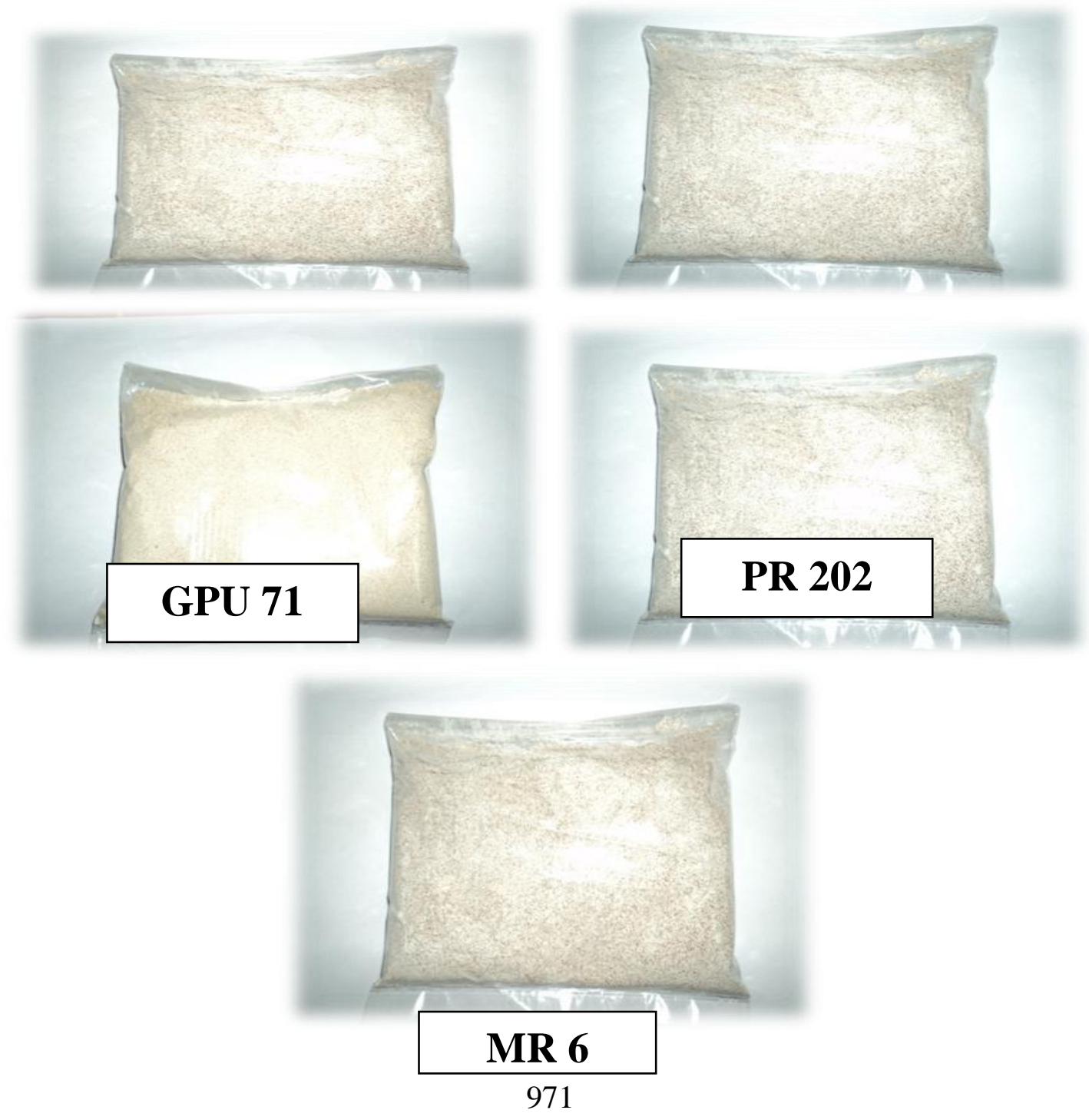
Plate.2 Popped finger millet varieties
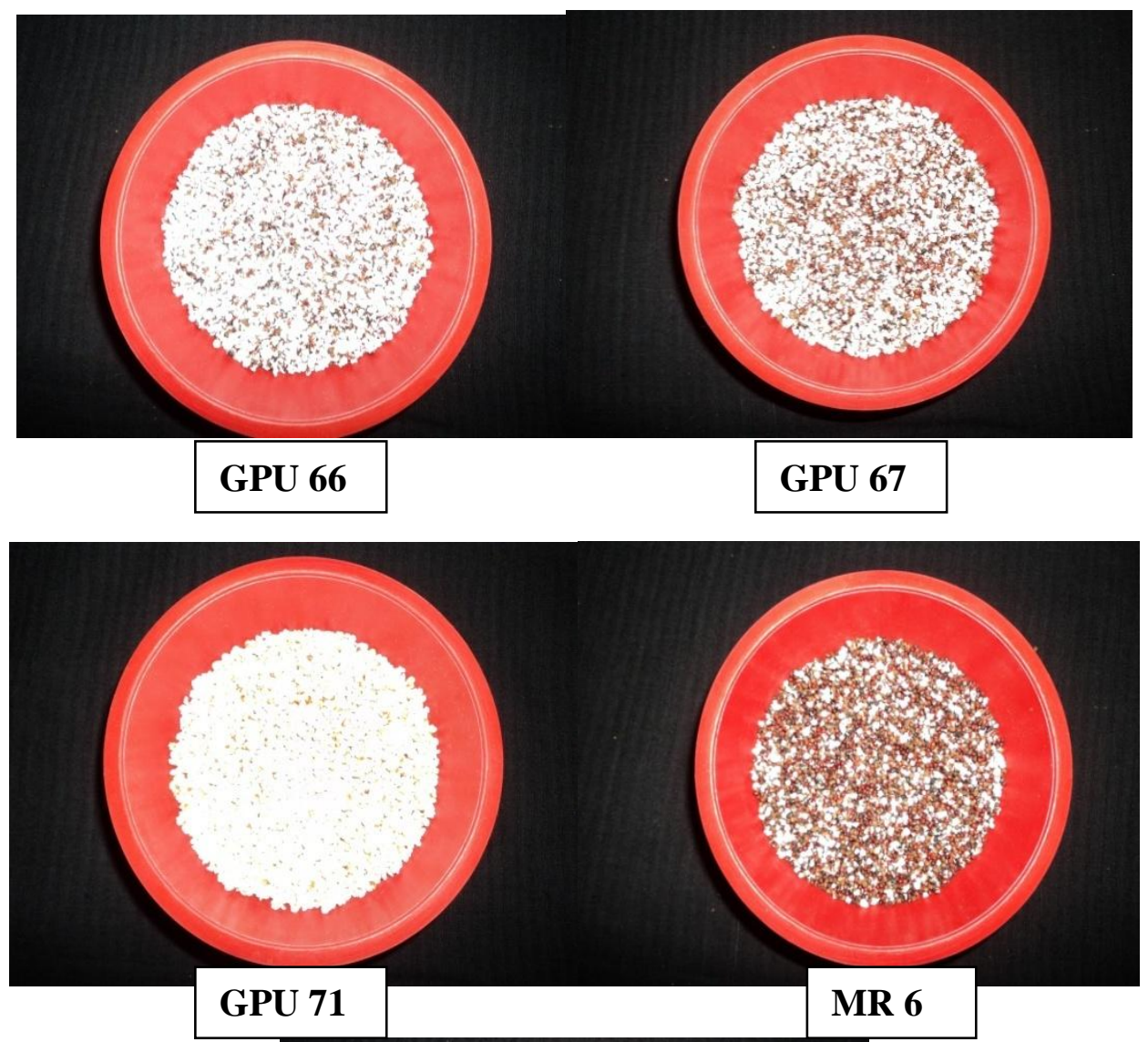

Millets in general, are rich in dietary fibre ( 9 to 15 per cent) (Hadimani and Malleshi, 1993). Similar trend was observed in raw finger millet varieties under study in which the mean TDF, SDF and IDF were found to be $12.15,2.73$ and $9.53 \mathrm{~g} / 100 \mathrm{~g}$. After malting and popping the TDF, SDF and IDF had reduced under study. The reason for lower fibre content in popped sample may be due to the removal of seed coat to some extent during popping, in malted form of finger millet it might be due to the type of grain, degree of removal of seed coat and exclusion of rootlets and shoots of sprouts (Choudhury et al., 2010). Thus the results of study on five finger millet varieties revealed that GPU 66 
and 67 whose malt recovery was slightly lower than that of GPU 71 were nutritionally better than other varieties. Hence these varieties are more suitable for preparing malt for children and elderly. From commercial point of view GPU 71 with highest malting and popping per cent can be exploited for developing malt and popped finger millet based products and is a good feedback for breeder.

\section{Acknowledgement}

The authors are grateful to Department of Food Science and Nutrition, University of Agricultural Sciences, Bengaluru, for providing the support to carry out the research. We would like to convey special thanks to the Project Coordinating Unit, All India Coordinated Small Millet Improvement Project (AICSMIP), GKVK, UAS, Bengaluru for the financial support for the research.

\section{References}

A.O.A.C., 1980, Official methods of analysis, $13^{\text {th }}$ Ed., Association of official Agricultural chemists, Washington, D.C.20044.

A.O.A.C., 1995. Official Methods of Analysis, Association of Official Analytical Chemists, International, $18^{\text {th }}$ edition, Washington D.C, Chapter 45, pp 71-72.

Choudhury, M., Das, P and Baroova, B., 2010. Nutritional evaluation of popped and malted indigenous millet of Assam. J. Food. Sci Technol. 48(6): 706-711.

Desai, D.A., Kulkarni, S.S., Sahoo, A.K., Ranveer, R.C., and Dandge, P.B., 2010. Effect of supplementation of malted ragi flour on nutritional and sensorial quality characteristics of cake. Advance J. Food. Sci. Technol, 2 (1): 67-71.

Gokavi, S.S. and Malleshi, N.G., 2000. Malting characteristics of a few Indian wheat and chickpea varieties. J Food Sci Technol., 37:586-591.

Gopalan, C., Rama Sastri, B.V. and Balasubramanian, S.C., 2007. Nutritive value of Indian foods. National Institute of Nutrition, ICMR, Hyderabad.

Hadimani, N.A. and Malleshi, N.G., 1993. Studies on milling, physicochemical properties, nutrient composition and dietary fibre content of millets. J. Food. Sci Technol., 30(1): 17-20.

Kumari, S. and Srivastava, S., 2000. Nutritive value of malted flours of finger millet genotypes and their use in the preparation of burfi. J. Food. Sci Technol., 37(4): 419-422.

Madhusmitha, Sahoo, 2003. MSc. Thesis, University of Agricultural Sciences, Bangalore.

Malleshi, N.G. and Deskachar, H.S.R., 1981. Varietal Differences in puffing quality of ragi. J. Food. Sci. Technol, 18(1): 3032.

Malleshi, N.G. and Klopfenstein, C.F., 1998. Nutrient composition and amino acid contents of malted sorghum, pearlmillet and finger millet and their milling fractions. J. Food. Sci Technol. Mysore., 35(3): 247-249.

Malleshi, N.G., Desikachar, H.S.R. and Tharanatha, R.N., 1986. Physicochemical properties of native and malted finger millet and foxtail millet starches, CFTRI. Starch Sterke (Germany, J.K.) 38(6): 202-205.

Pawar, V. S. and Pawar, V.D., 1997. Malting characteristics and biochemical changes of foxtail millet. J. Food. Sci. Technol, 34(5): 416-418.

Premavalli, K.S., Satyanarayanaswamy, Y.S., Madhura, C.V., Majumdar, T.K., Bawa, A.S., 2005. Effect of pre-treatments on the physic-chemical properties of puffed ragi (finger millet) flour. J. Food. SciTechnol, 42(5):443-445.

Shayo, N.B., Tiisekwa, B. P. M., Laswai, 
H.S., and Kimaro, J.R., 2001. Malting characteristics of Tanzania finger millet varieties. Food and Nutrition Journal of Tanzania, 10: 1-4.

Shukla, S.S., Gupta, O.P., Sharma Y.K. and Swarkar, N.S., 1986. Puffing quality characteristics of some ragi cultivars. $J$.
Food. Sci Technol, 23(6): 329-330.

Wadikar, D.D., Premavalli, K.S, Satyanarayanaswamy, Y.S and Bawa, A.S., 2007. Lipid profile of finger millet (Eleusine coracana) varieties. J. Food. Sci. Technol, 44(1): 79-81.

\section{How to cite this article:}

Soubhagyalaxmi P. Hiremath and Geetha, K. 2019. Nutritional Composition of Raw, Malted and Popped Finger Millet (Eleusine coracana) Varieties. Int.J.Curr.Microbiol.App.Sci. 8(02): 966-974. doi: https://doi.org/10.20546/ijcmas.2019.802.112 